\title{
Practice-Oriented Forms of Scientific and Technical Creativity of Gifted Youth
}

\author{
Yazglem Davletshina \\ Dept. «Foreign languages» \\ Kazan state power engineering university \\ Kazan, Russia \\ yazgul_ahmetova@mail.ru
}

\author{
Radmila Khizbullina \\ Dept. «Sociology, politology and law» \\ Kazan state power engineering university \\ Kazan, Russia \\ mine_post@inbox.ru
}

\begin{abstract}
This article explicates the specifics of the scientific and technical creativity of gifted youth as creative activities to create material and technical products and means in order to optimize the social and economic development of society. The methodological approaches to the study of the phenomenon of scientific and technical creativity of gifted youth are analyzed; from empirical position, the importance of the development of practice-oriented forms of scientific and practical activity of gifted youth for their professional selfrealization, competitiveness and, as a result, innovation of socially significant areas of society is proved. Based on the results of sociological research, the necessity of introducing practice-oriented forms of scientific and technical creativity into the activities of organizations working with gifted youth is proved as determinants, promoting the innovative development of regional clusters, for the formation of positive dynamics of distribution of youth project activities forms.
\end{abstract}

Keywords: science, scientific and technological creativity, practice, gifted youth, competitiveness, practice-orientation

\section{INTRODUCTION}

Support and development of the creative potential of gifted youth is one of the important tasks of state youth policy. In modern conditions, scientific and technical creativity is the basis of innovation. Therefore, the process of developing scientific and technological creativity is an essential component of the modern education system. Learning the fundamentals of scientific and technical creativity, the implementation of practice-oriented forms of scientific and technical creative work will help future specialists to increase professional and social activity, which in turn will lead to conscious professional self-determination in professions in the technical sphere, increase productivity and quality of labor, accelerate of development of the scientific and technical sphere of production [1].

\section{MethodS AND RESUltS}

Scientific and practical education combines research and design activities, scientific and technical creativity of students. Its main tasks are the development of the subjective position of students (the personal result); formation of a scientific picture of the world, the development of skill, the creation and implementation of projects for the development of elements of the scientific method of cognition, acquisition of technical and technological knowledge and skills, the motivation for professional self-determination in science and technology, development of reflection skills of one's own activity [2].
The system of scientific and practical education involves the integration of education with high-tech scientific and industrial enterprises on special sites (lyceums, institutions for additional education of children, technology parks at the largest scientific and production associations, etc.); the continuity of the development of scientific and technical culture and motivation of students from primary school to specialized departments in the territories of production [3]. In general, the listed activities ensure a stable position of specialists in the labor market, as well as the development of career and professional development paths [4].

The works of the classics of sociology, pedagogy, social psychology were devoted to the problem of studying the scientific and technical education, reproduction of human capital from the point of view of sociological knowledge. In their works, representatives of sociological science from various positions examined the features of training young specialists, conversion of human capital into innovative forms of productive activity [5,6,7] and education of the young generation through implementation of educational practice-oriented strategies $[8,9,10]$. In the works of foreign $[11,12]$ and domestic $[13,14]$ contemporary researchers from methodological positions, the study of the issues of training young specialists, talented youth from the point of view of practice-oriented training using innovative forms of scientific creativity is updated.

In general, the forms and methods of educational activity can be presented as follows:

- Form - a group mini-project, which includes collectively distributed forms of activity and involves achieving the final result within several hours, during which the event is held;

- Diagnostic methods - protection of collective project in front of the participants of the event with mutual expertise and expert examination;

- Functions - the acquisition of elementary ideas about the standards of design or research as types of activity, the development of elementary cycles of design and research;

- Material development methods - transfer of elementary information on the subject of an event, 
inclusion in the project activities; translation of educational program material, organization of individualized forms of work;

- Forms of educational activity - work of an autonomous group of students on the educational program of departure, visiting professional institutions and organizations, real objects;

- Diagnostic methods - the student report about the nature and extent of material collected, key travel results;

- Functions - expanding the boundaries of the educational process, inclusion of real objects, social, professional activity;

- Material development methods - practical study, search, design, research activities at real objects.

\section{DISCUSSION}

Scientific and practical education has the following functions with respect to different populations of students. This implies various goals of its implementation, methodological base, results, methods of their diagnosis. However, three subsystems should be closely linked.

Formation of elements of scientific and technical culture [15] among talented youth involves the organization of mass scientific and practical education in higher educational institutions in order to increase attention of young people to technical creativity, the development of specialized competences, skills in the field of design and research activities and scientific and technical creativity [16]

Identification, development and support of talented and gifted in various fields of science and technology requires modern materials and technical base and qualified teaching staff to expand ties with scientific institutions, high-tech production enterprises; the creation of integrated educational complexes providing effective paths of professional selfdetermination of such students on the basis of leading higher education institutions [17].

Scientific and practical education is the most important direction of modern education and allows to solve following tasks:

- improving the worldview and technological culture of talented children and youth on the basis of active development of knowledge and achievements of modern scientific and technical civilization (including special contingents of pupils - with disabilities);

- improvement the quality of education based on the development of motivation of students for scientific and technical creativity and the creation of conditions for practical activities using modern material and technical resources under the leadership of the experts with advanced technologies;

- increasing the accessibility of education based on the implementation of the model of lifelong education involving stage-by-stage inclusion of students in the development of the content of scientific and practical education in various forms and at different levels (Houses of creativity, collectives at higher education institutions, scientific research institutes, the enterprises, etc.) and within distance interactive educational programs;

- development of convergent education which involves the integration of knowledge in different fields of science and technology through the implementation of cross-disciplinary projects (a design and research game).

One of the important ways of involving young people in scientific activity is to attract a young specialist at an early age as a senior student in serious scientific activity. Thus, according to the results of the sociological study, (data of the survey conducted in 2009 - 2011 among young scientists of the Republic of Tatarstan. The survey was carried out by a temporary scientific team with the participation of authors) $54 \%$ of creative youth are actively engaged in scientific research and, even in student years were involved in scientific work; $(52 \%)$ of respondents are recommended for postgraduate studies by the scientific head of diploma or qualification works or by the department (faculty); $61 \%$ of respondents said that they like to fulfill scientific research, of which $25 \%$ believe that scientific activity is promising; $21 \%$ of respondents consider the occupation of scientific and technical creativity to be a demanded area of activity.

In the process of implementing scientific and practical education within the framework of scientific and technical creativity of talented young people at each level they stepby-step immerse themselves(in accordance with inclinations and abilities) in the corresponding problems, during which there is an increase in motivation to study the subject, mastering the material, access to individual innovative projects solving the problems.

At each level of development (from initial motivation to designing their own educational trajectory), specific forms of participation are realized, in which young talents interact with specialists (from teacher of additional education to scientific community) in solving problems of the corresponding level, thus, including in increasingly complex educational and professional communities, mastering new types of communication, realizing their innovative potential $[18,19]$.

\section{CONCLUSIONS}

Thus, scientific and technical creativity thanks to the modern scientific and technical revolution as electronic, computer and information is realized in innovative forms in comparison with the era of industrial revolution, mechanization and electrification of the spheres of production, transport and life. The modern level of innovation and technological development of the revolution requires to provide space for the scientific and technical creativity of talented youth as the initial impetus of social and technical-technological changes in the productive forces. At the same time, the space of scientific and technological creativity itself cannot provide productive forces, because the realization of innovations generated in the sphere of scientific and technical creativity is possible only in the sphere representing the organic unity of production, distribution, exchange and consumption of knowledge, which is implemented at the stages of integration of scientific and technical creativity classes into educational activities [20]. 
[13] Y. A. Zubok and V. I. Chuprov, "Young specialists: problem of preparation and situation on the labor market," Sociological researches, no. 5, 2015, pp. 114-122.

[14] Yu. A. Zubok and V. I. Chuprov, "Formation and development of Russian youth sociology," Sociological Research, no. 7, 2008, pp. 108-117.

[15] P. A. Sorokin, Social and cultural mobility, Person. Civilization. Society, Moscow: Politizdat, 1992, 543 p.

[16] Y. M. Davletshina, L. K. Mukhametzanova, and R. R. Khizbullina, "Monitoring of the state and the prospects of development of talented youth in modern conditions," TOJDAC, December 2017.

[17] T. Emchura, "Modern youth and channels of its socialization," Westn. Mosk. un-that. no. 18, Sociology and Political Science, no. 3, 2006, pp. 135-141.

[18] R. R. Khizbullina, L. K. Muhametzanova, and S. A. Alekseev, "Las perspectivas de preservación de las profesiones de trabajo entre los jóvenes en el complejo agroindustrial a la República de Tatarstán," Revista Dilemas Contemporáneos, Educación, Política y Valores, VI Número, art. no. 66, Período Diciembre 2018 [Electronic source]. Available http://www.dilemascontemporaneoseducacionpoliticayvalores.com.

[19] Ya. M. Davletshina, L. K. Mukhametzyanova, and R. R. Khizbullina, "Social well-being and creative mobility of talented youth of the Republic of Tatarstan," Management of sustainable development, no. 5 (12), 2017, pp. 44-48.

[20] A. M. Seleznev, "Scientific and technical creativity and economic thinking in the conditions of Soviet society," Philosophy and society, no. 2, 2002, pp. 163-178.

[10] E. Durkheim, Education and Sociology, N.Y.: The Free Press, 1956. development of American Physics Olympians," Gifted and talented international, no. 16 (2), 2001, pp. 108-114.

[12] R. F. Subotnik and K. D. Arnold (eds), Westinghouse science talent search winners, Beyond Terman: Contemporary longitudinal study of giftedness and talent, Norwood, N.Y.: Ablex, 1995, pp. 52-76. 